\title{
A report of Stephanosphaera pluvialis CoHN 1852 (Chlorophyta, Chlamydo- phyceae)
}

\author{
Jan KAŠTOVSKÝ
}

Faculty of Sciences, University of South Bohemia, České Budějovice, e-mail: hanys@prf.jcu.cz

\begin{abstract}
An interesting and rare alga was found after 43 years in the Czech Republic. This short note focuses on review of localities and morphological evaluation of found population.
\end{abstract}

Key words: Stephanosphaera pluvialis, rain pool, Ostaš Hill

The green colonial flagellate alga Stephanosphaera pluvialis COHN 1852 (from the Greek words "stephanos" = crown and "sphaira" = ball and Latin "pluvius" = rainy) is a rare organism reported from rain pools on non-basic rocks and very rarely from lakes. It is infrequently reported from Europe (Wawrik \& Sandmann 1984, Pentecost 2002). More often has been mentioned only by SKUJA (1956) from south and central Sweden, and by Sмітн (1950) from Lake Echo in the United States. Pringsheim isolated a $S$. pluvialis strain CCAP 78/1B and 1D from Lake Erken, Sweden, (WWW.CCAP.AC.UK); few localities are situated along the River Dnjestr (south Russia, SWIRENKo in PASCHER 1927).

Although the species has been mentioned in handbooks (FoTT 1956, HINDÁK et al. 1978 and SLÁDEČEK \& SLÁDEČKOVÁ 1996) the majority of Czech records is more than 50 years old:

Grunov Village, northern, mostly sandstone hills; Doksy area, locus classicus (CoHN 1852); Labské pískovce Mts. (PASCHER 1927); Krušné Hory Mts., Děčínský Sněžník, Bernstein and Hejšovina Hill (HANSGIRg 1889) and Jindřichův Hradec in the South Bohemia (PASCHER 1927). Czech algal database summarizing more recent data (PoulíčKovÁ et al. 2004) includes only two later records: Smolný Hill and Žulová nearby town Jeseník (CzUDEK et al. 1964).

The morphologically based taxonomical classification of $S$. pluvialis to the order Chlamydomonadales and family Haematococcaceae (EтTL 1983) is supported also by molecular results (Buchнеiм et al. 1997).

The material was collected on $15^{\text {th }}$ of April 2007 in a small artificial rain pool $(15 \mathrm{~cm}$ in diameter, ca. $15 \mathrm{~cm}$ deep) on sandstone on Frýdlantská skála in Ostaš Hill nearby Police nad Metují (Hradec Králové region). The water was intensely green colored and contained an interesting community - Dictyosphaerium sphagnale HINDÁK as the dominant species and Stephanosphaera pluvialis as the subdominant, with rarely occurring Haematococcus pluvialis FLOTOW.

The living sample was observed by light microscope Olympus BX 51, pictures were obtained using digital camera Olympus Camedia C-5050 ZOOM and software Quick PHOTO MICRO 2.2.

Cells are elongate or ellipsoid; with very remarkable cytoplasmic processes from both cell poles and rarely from the central portion. Biflagellate cells contain a reticulate chloroplast, a visible stigma and two pyrenoids (Figs 1, 3).

Cells are aggregated in regular spherical colonies consisting of 8 cells constantly in inspected population. In literature (PASCHER 1927, ETTL 1983) 2, 4, 8 or 16 cells are mentioned and sometimes ellipsoid shape colonies. Size of colonies is 55-75 $\mu \mathrm{m}$ (slightly larger than described in literature (PASCHER 1927, ETTL 1983, 30-60 $\mu \mathrm{m})$. Cells are located under colony surface in a gelatinous envelope. Cells from young colonies are concentrated to one equatorial ring and its shape is spherical or slightly elongated $(7-16 \mu \mathrm{m})$ without cytoplasmic processes. Young cells are spherical and they get elongate later, and the consequent final size of cells are 18-21 (plus length of processes 14-19 $\mu \mathrm{m}$ ) $\times$ $8.5-11 \mu \mathrm{m}$. The elongation process is not symmetric; cells in old colony are closer to one pole that to the other (make "crown like ring" - see etymology).

Production of gametes $(9-11 \times 3-3.5 \mu \mathrm{m})$ is documented on Fig. 2. Zygotes or asexual reproduction by formation of autocolony were not observed.

I thank Karolina Fučíková for language revision 


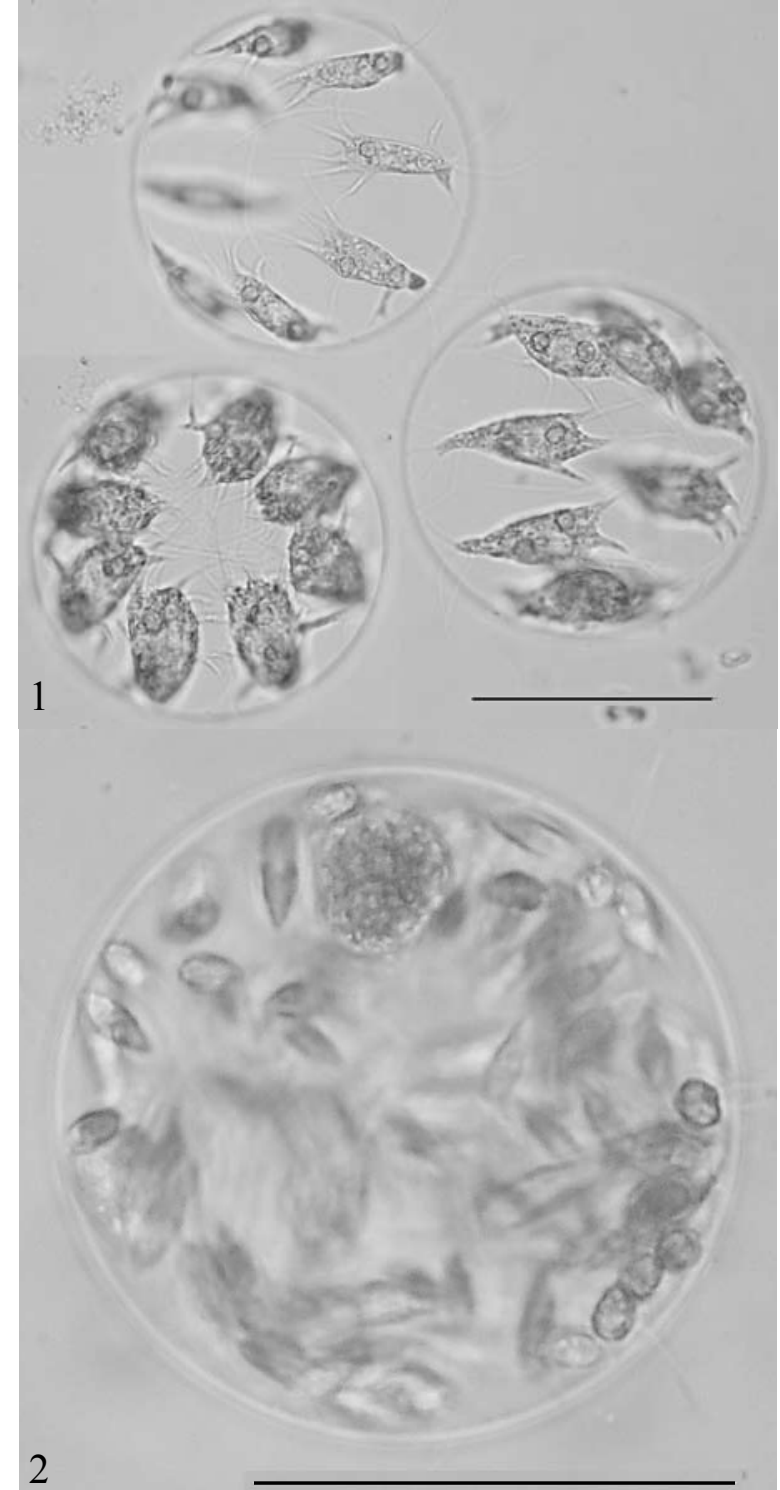

2

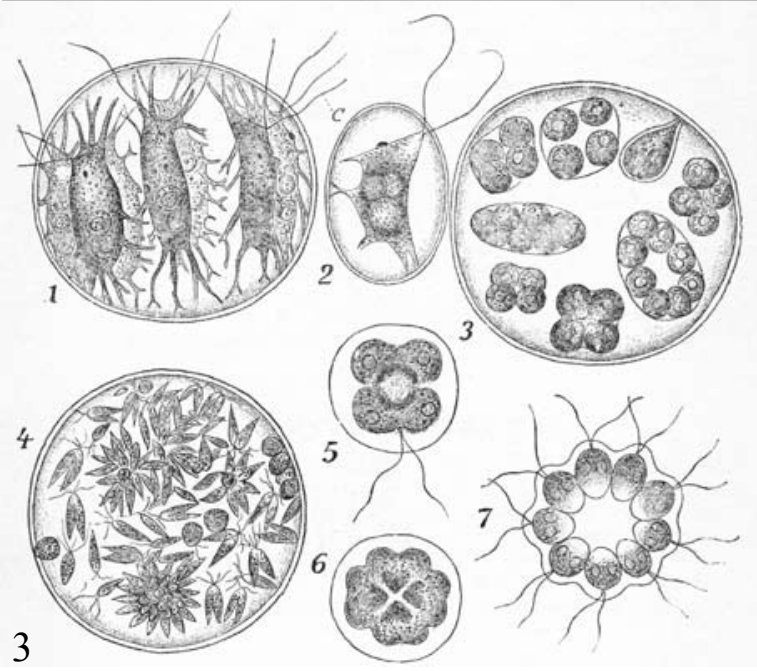

Fig. 1. Characteristic are cytoplasmic processes which connect cells to the one pole of the colony. Fig. 2. Production of gametes. Fig. 3. Correct and detailed line drawing of Stephanosphaera pluvialis (Hieronymus 1884 in PASCHER 1927): 1 - mature colony; 2 - solitary cell; 3 - autocolony formation; 4 - formation of gametes; 5-7 - young colony. and prof. Jiří Komárek for valuable comments. This study was supported by grant MSM 6007665801.

\section{References}

Buchheim, M. A., Buchheim, J. A. \& Chapman, R. L. (1997): Phylogeny of Chloromonas: A study of 18 S ribosomal RNA gene sequences. - J. Phycol. 33: 286-293.

CoHN F. (1852): Über eine Gattung aus der Familie Volvocineen. - Z. Wiss. Zool. 4: 77-116.

Czudek T., Demek J., Marvan P., Panoš V., Raušer J. (1964): Verwitterungs- und Abtragungsformen des Granits in der Bohmischen Masse. - Petermanns Geographische Mitteilungen 3:182-192.

EтtL, H. (1983): Chlorophyta 1. Phytomonadina. - In: EtтL, H., Gerloff J., Heynig H. \& Mollenhauer D. (eds.): Süßwasserflora von Mitteleuropa 9: 1-807 pp., Gustav Fischer Verlag, Stuttgart - New York.

Fотт B.(1956): Sinice a řasy. - 372 pp., Nakladatelství Československé akademie věd, Praha.

HANSGIRG, A. (1889): Prodromus českých řas sladkovodních, díl prvý. - In: Archív pro přirodovědný výzkum Čech, V/6 (botan.oddělení): 1-182 pp., Praha.

Hieronymus G. (1884): Über Stephanosphaera pluvialis. Beitr. Biol. Pfl. 4: 51-78.

Hindák, F., Cyrus, Z., Marvan, P., Javornický, P., Komárek, J., Ettl, H., Rosa, K., SládečKová, A., PopovskÝ, J., Punčochár̆ová, M. \& LhotskÝ, O. (1978): Sladkovodné riasy. -728 pp, Slovenské pedagogické nakladatelstvo, Bratislava.

Pascher, A. (1927): Volvocales. - In: Pascher, A. (ed.): Süßwasserflora Deutschlands, Österreichs und der Schweiz H 4: 1-506 pp., G. Fischer, Jena.

Pentecost, A. (2002). Order Volvocales. - In: John, D. M., Whitton, B. A. \& BRook, A. J. (eds): The Freshwater Algal Flora of the British Isles. An identification guide to freshwater and terrestrial algae. - 327 pp., Cambridge University Press, Cambridge.

PoulíčKovÁ, A., Lhotský, O. \& Dřímalová, D. (2004): Prodromus sinic a řas České republiky. - Czech Phycology 4: 19-33.

SKUJA, H. (1956): Taxonomische und biologische Studien über das Phytoplankton schwedischer Binnengewässer. - Nova Acta Reg. Soc. Sci. Upsal., Serie IV., 19/3: $1-104$.

SlÁdeČEK, V. \& SládeČKovÁ, A. (1996): Atlas vodních organismů se zřetelem na vodárenství, povrchové vody a čistírny odpadních vod, 1. díl: Destruenti a producenti. - 350 pp., Česká vědeckotechnická vodohospodářská společnost, Praha.

Sмiтh, G. M. (1950): Freshwater algae of the United States. - 719 pp., McGraw-Hill Book Company, Inc., New York- Toronto- London.

Wawrik, F. \& SAndmann, L. (1984): Algen-Besiedlung zweier periodish austrocknender granitmulden im Waldviertel (Nieder-Österreich). - Phyton 24: 239 252.

WWW.CCAP.AC.UK

(C) Czech Phycological Society

Received August 27, 2007

Accepted January 19, 2008 